\title{
Effect of discipline on employee performance through total quality management as mediation variables
}

\author{
Stanley Ferdinandus ${ }^{\mathbf{a}^{*}}$
}

${ }^{a}$ Politeknik Negeri Ambon, Indonesia

\begin{tabular}{|c|c|}
\hline CHRON I C L E & A B S T RACT \\
\hline $\begin{array}{l}\text { Article history: } \\
\text { Received: February } 10,2020 \\
\text { Received in revised format: } \\
\text { March } 202020 \\
\text { Accepted: April 10, } 2020 \\
\text { Available online: } \\
\text { April 12, } 2020 \\
\text { Keywords: } \\
\text { Discipline } \\
\text { Total Quality Management } \\
\text { Performance }\end{array}$ & $\begin{array}{l}\text { The purpose of this study was to analyze the effect of work discipline on the performance of Ambon } \\
\text { State Polytechnic education staff and analyze the effect of work discipline on performance through } \\
\text { Total Quality Management (TQM) in Ambon State Polytechnic education staff. Respondents in } \\
\text { this study were } 100 \text { Ambon State Polytechnic education staff. The analytical model used to } \\
\text { determine the effect between variables is a structural model with the Partial Least Square (PLS) } \\
\text { approach. The results show that work discipline directly affected the performance of educational } \\
\text { staff by } 20.6 \% \text { and the indirect effect of work discipline affected the performance of the education } \\
\text { staff through Total Quality Management of } 38.7 \% \text { which means that the practice of TQM is able } \\
\text { to provide a considerable influence in improving the performance of educational staff. To improve } \\
\text { the performance of educational staff, work discipline should be directed at the TQM process in } \\
\text { advance so that the work process is more directed. }\end{array}$ \\
\hline
\end{tabular}

C 2020 by the authors; licensee Growing Science, Canada

\section{Introduction}

In today's global competition, people talk about quality, especially those who discuss the work that produces products or services. A product is made because of a need, and that need develops along with the quality of its users, as well as improvements for the environment from local to global changes that cause changes in all sectors of life. There is a global need to adjust, making managers not only discuss at the local, national or regional level, but must compete. There is only one company to overcome this, namely to improve, both to improve the quality of the resources that are owned. The quality of human resources can increase competition in improving business towards the progress of a company (Yasin et al., 2019). By using a good management system through management, it is important to improve company performance through the performance of its employees. To achieve organizational goals one of the most important things is associated with work discipline. Employee discipline is the nature of an employee who consciously complies with certain organizational rules and regulations. Discipline can be seen as a form of judgment for employees in implementing organizational rules. The higher the discipline, the higher employee work productivity and organizational performance. One of the commonly used quality management tools is Total Quality Management (TQM). Organizations that implement TQM aim to meet customer satisfaction and expectations, the demands of changing environments and the demands of the organization itself. The effective implementation of TQM has a positive influence which will ultimately benefit the organization. TQM focuses on services and workforce involvement and it is expected to affect the performance of the company. Related to employee performance, basically the implementation of TQM carried out in a planned and directed manner is expected to help in increasing employee productivity and performance (Poernomo et al., 2006). Therefore, companies need to create an appropriate performance measurement system to determine the characteristics and quality of performance and identify actions that can be taken in an 
effort to increase employee productivity. The more often a company measures employee performance, the more company will improve the performance of its employees, and the increase in performance will have an impact on improving quality. Empirically, the results of a study on the impact of implementing TQM on employee performance are shown by Therese (2007) who found a strong positive relationship between the level of implementation of TQM practices and organizational performance. Then Al-Shobaki, et al. (2010) also found evidence that implementing TQM can improve organizational performance as reflected in efficiency and productivity. In contrast, the findings of Enny (2015) show that TQM does not have a positive and significant effect on employee performance. From the research findings, it is known that the application of TQM can affect employee performance, although the influence may be different in each company (Ismunawan, 2010). In improving the performance of the Ambon State Polytechnic educational staff, employees are required to do their jobs properly. In Ambon State Poblytechnic, there are several people who are excellent in completing their tasks not on time, the lack of responsibility and commitment in carrying out the task, the lack of trained personnel that can be seen from the presence of employees who are waiting for orders to do the work and often delayed work. From this phenomenon there was a decrease in the level of work discipline, making the education staff not eager to work, the sense of responsibility is reduced, and inconsistent in doing the work.

\subsection{Research Problem}

1. What is the effect of discipline on the performance of the Ambon State Polytechnic educational staff?

2. What is the effect of discipline on performance through total quality management on the Ambon State Polytechnic educational staff?

\subsection{Objectives of the Research}

1. Analyze and assess the effect of discipline on the performance of the Ambon State Polytechnic educational staff,

2. Analyze and assess the effect of discipline on performance through TQM of Ambon State Polytechnic education staff.

\section{Literature Review}

\subsection{Discipline}

Discipline comes from Latin, namely discipline which is defined as training or education, character development, and politeness. One aspect of the strength of Human Resources (HR) can be reflected in the attitude and behavior of the discipline, because discipline has a strong impact on an organization to achieve success in pursuing planned goals. Discipline is the most important operative function of human resource management since the better employee discipline is, the higher the achievement or performance is achieved and will create quality employees. Discipline is very important for organizational growth, especially for employees to discipline themselves in carrying out work both individually and in groups. Keith Davis in Mangkunegara and Prabu (2013), stated that "discipline is management action to enforce organization standards". Based on the opinion of Keith Davis, work discipline can be interpreted as the implementation of management to reinforce organizational guidelines. Then according to Sulistyani and Rosidah (2003), discipline is a procedure that corrects or punishes subordinates for violating rules or procedures, discipline is a form of employee self-control and regular implementation and shows the level of sincerity of work teams in an organization. According to Siagian (2006), discipline is training, specifically training mind and attitude to produce self-control, self-habits to comply with applicable regulations. So, someone will be willing to obey all the rules and carry out their duties, both voluntary and forced. Discipline means that employees always come and go home on time, do all their work well, comply with all applicable rules and social norms. According to Mangkunegara and Prabu (2013), there are 2 forms of work discipline, namely preventive discipline and corrective discipline. 1). Preventive Discipline, Preventive Discipline is a must to move employees to follow and approve work, the rules that the company has outlined, 2). Corrective Discipline, Corrective Discipline is an effort to move employees in uniting a regulation and directing it to keep abiding by the rules in accordance with the guidelines that apply to the company. Discipline is an HRM function that is a benchmark to measure or find out whether other HR functions as a whole have been implemented properly or not. Good employee discipline, reflect that other HRM functions have been carried out according to plan. Conversely, if employee discipline is not good, it means that the application of HRM functions is not good.

\subsection{Total Quality Management}

Total Quality Management consists of several instruments and quality techniques, in addition to the various values and beliefs held by all staff in the same organization (Gharakhani et al., 2013). TQM can be defined as a strategy that aims to produce and transfer services that are more efficient and superior, through achieving collaboration between members of the organization (Lakhal et al., 2006). Various things are done to improve the quality that is applied to the company's products, services and management. Along with the development of science, an innovation is known as TQM. According to Tjiptono and Diana (2003), TQM is an approach in increasing organizational productivity (quantitative performance), improving quality (reducing errors and damage levels), increasing the effectiveness of all activities, increasing efficiency (reducing 
resources through increasing productivity), and doing everything correct in the right way. The definition of Total Quality Management according to Handoko, (2008) is as follows:

1. Total : Total Quality Management is a comprehensive organizational strategy that involves all levels of management and employees, not only end users and external buyers, but also internal customers, suppliers, and even support personnel.

2. Quality: TQM places more emphasis on quality service, not just defect-free products. Quality is defined by the customer, customer expectations are individual, depending on socioeconomic background and demographic characteristics

3. Management: TQM is a management approach, not a narrow quality control technical approach.

From the understanding of the experts above, Total Quality Management can be broadly interpreted as a strategy and management philosophy that tries to integrate all organizational functions that involve all managers and employees to work together in improving products, services, people, processes, and the environment so as to optimize the performance of employees of the company. The rationale for the need for TQM is very simple, namely that the best way to compete and excel in global competition is to produce the best quality. To produce the best quality, continuous improvement efforts are needed for human capabilities, processes and the environment. The best way to continually improve component capabilities named TQM. The application of TQM in a company can provide several key benefits which in turn increase the profit and competitiveness of the company concerned.

\subsection{Employees Performance}

According to Hasibuan (2008) "Performance is the result of work achieved by a person in carrying out the tasks assigned to him based on skill, experience, sincerity and time". Meanwhile, according to Suyadi Prawirosentono (2008) "Performance is work results that can be achieved by a person or group of people in an organization, in accordance with their respective authorities and responsibilities in an effort to achieve the objectives of the organization concerned legally, does not violate the law and in accordance with morals and ethics. Hasibuan (2008) revealed that "Performance is a combination of three important factors, namely the ability and interest of a worker, the ability and acceptance of the delegation's assignment and role and the level of motivation of workers". If the performance of each individual or employee is good, then company performance is expected to be good too. Performance is the result of quality and quantity of work achieved by an employee in carrying out their duties in accordance with the responsibilities given to him (Mangkunegara \& Prabu, 2006). Performance opportunities need to be further strengthened even though an employee may be willing and able. According to Wirawan (2009) "Performance standards are targets, targets, goals of work effort of employees within a certain period of time. In carrying out its work, employees must direct all energy, thoughts, skills, knowledge, and work time to achieve what is determined by performance standards". There are three basic types of performance criteria, namely:

a) Criteria based on nature (focusing on personal characteristics of an employee),

b) Criteria based on behavior (criteria that are important for jobs that require interpersonal relationships),

c) Criteria based on results (criteria that focus on what has been achieved or produced).

To achieve employee performance objectives, we may need different things, including: appraisal must have a relationship with work, the existence of work performance standards, practical (easily understood or understood by employees or appraisers). Employees want feedback regarding their achievements. If performance does not meet the standards, then the assessment provides an opportunity to review employee progress and develop performance improvement plans. According to Bohlander et al. (2004) performance variables are summarized as follows,

1. Overall quality is the employee's perception of the overall quality of work. Quality perception is an overall picture of the perception of inputs and outputs in a process. Input in the form of all the resources is used to carry out a process while the output is the result (outcome) of a process.

2. Reliability is the employee's perception of the quality of work that has been obtained by the employee is accurate / in accordance with existing information and can be trusted. Reliability is the consistency of the results of input to output comparison. The more stable the results obtained, the more consistent.

3. Employee quality is the perception of the quality of the workforce concerning the suitability of capabilities and capabilities after carrying out their work. The quality of workers is the level of ability, capacity and capability of employees in completing their work.

Based on the brief discussion, the proposed study of this paper is summarized as Fig. 1 as follows, 


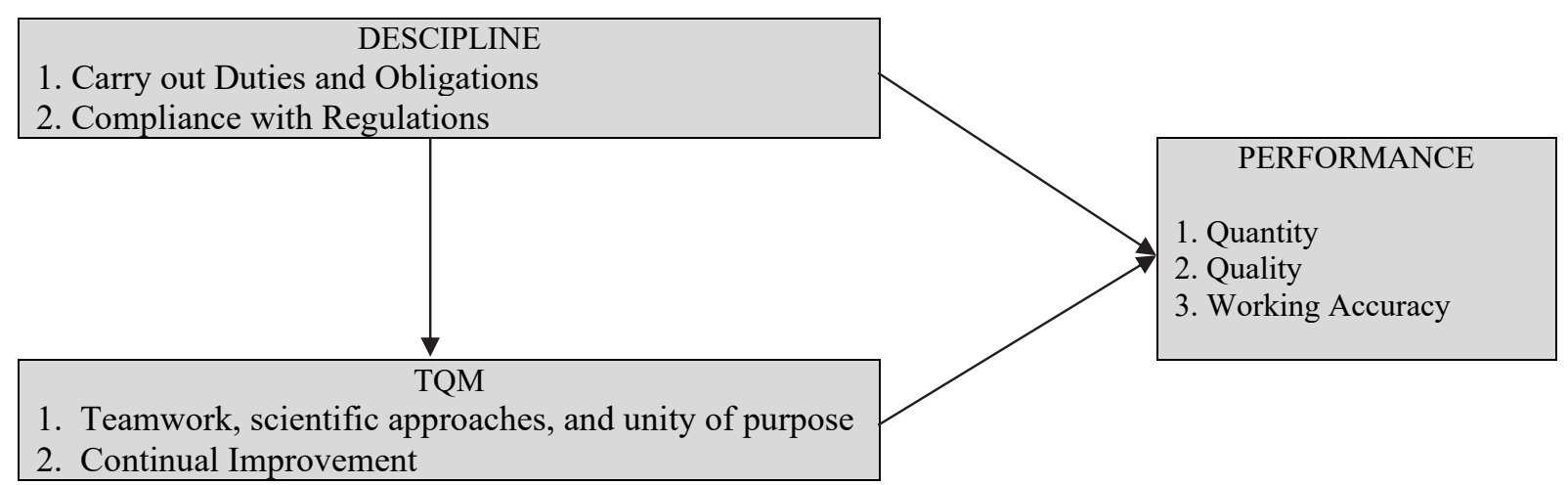

\section{Hypothesis}

Fig. 1. Conceptual framework

H1: Discipline influences the performance of the Ambon State Polytechnic education staff.

H2: There is a disciplinary effect on performance through Total Quality Management in the Ambon State Polytechnic educational staff.

\section{Research methods}

\subsection{Research sites}

This research was conducted at Ambon State Polytechnic.

\subsection{Population and Samples}

The population used in this study included all 100 educational staff in the Ambon State Polytechnic.

\subsection{Data analysis method}

This research was conducted at Ambon Polytechnic which was involved with 100 educational staff. Quantitative data were analyzed using descriptive and structural analysis Equation Modeling (SEM). In the analysis according to Ghozali (2006), path analysis the model of all latent variables in Partial least square (PLS) consists of three sets relationship. First, the model determines the relationship between latent variables (structural model). Second, the outer model determines the relationship between latent variables and measurement model. Third, the weight relationship is where the value of the latent variable case can be estimated.

\subsubsection{Inner Model}

The inner model, also called inner relations and substantive theory, describes the relationship between latent variables based on the substance of the theory. The equation model is as follows:

$$
\eta=\beta_{0}+\beta \eta \mid+\Gamma \xi+\zeta .
$$

The above formula describes the endogenous (dependent) vector of latent variables. The simbol of $\xi$ is a vector of exogenous latent variables. The symbol of $\zeta$ is associated with unexplained variance. PLS is disigned for recursive models. Therefore, there is a relationship between latent variables, each dependet latent variable, or often called the causal chain system of latent variables.

\subsubsection{Outer Model}

An Outer model is also called outer relation or measurement model, it defines how each indicator block is related to its of latent variables. The Outer models of a block with a reflexive indicators can be indicated by the following eguation :

$$
\begin{aligned}
& x=\Lambda_{x} \xi+\varepsilon_{x} \\
& y=\Lambda_{y} \eta+\varepsilon_{y}
\end{aligned}
$$


$x$ and $y$ are indicators or manifest variables for exogenous $\xi$ and endogenous $\eta$ latent variables. Meanwhile, $\Lambda_{\mathrm{x}}$ and $\Lambda_{\mathrm{y}}$ are loading matrix that describe a simple regression coefficients that connects latent variables to the indicator. Residuals measured by $\varepsilon_{\mathrm{x}}$ and $\varepsilon_{\mathrm{y}}$ can be interpreted as measurement errors or noise .

\subsubsection{Weight Relation}

Inner and outer models provide the specifications followed in the estimation of the PLS algorithm. We need to define the relationship weights with weight relations. The values of the case latent variable is estimated in PLS as follows :

$$
\begin{aligned}
\xi_{b} & =\Sigma_{k b} w k b \times k b \\
\eta i & =\Sigma_{k i} w k i y k i
\end{aligned}
$$

$w_{k b}$ and $w_{\mathrm{ki}}$ are $k$ weights used to form estimated of latent variables $\xi_{b}$ and $\eta_{i}$. Estimation of Latent variable are linear aggregate of indicators whose weight values are obtained from PLS estimation procedures such as specified by the inner and outer models where $\eta$ is an endogenous (dependent) and $\xi$ is an exogenous (independent) vector of latent variables. The symbol $\zeta$ represent residuals vector and $\beta$ and $\Gamma$ arethe path coefficients matrix.

\section{Research result}

Fig. 2 shows the results of SEM implementation.

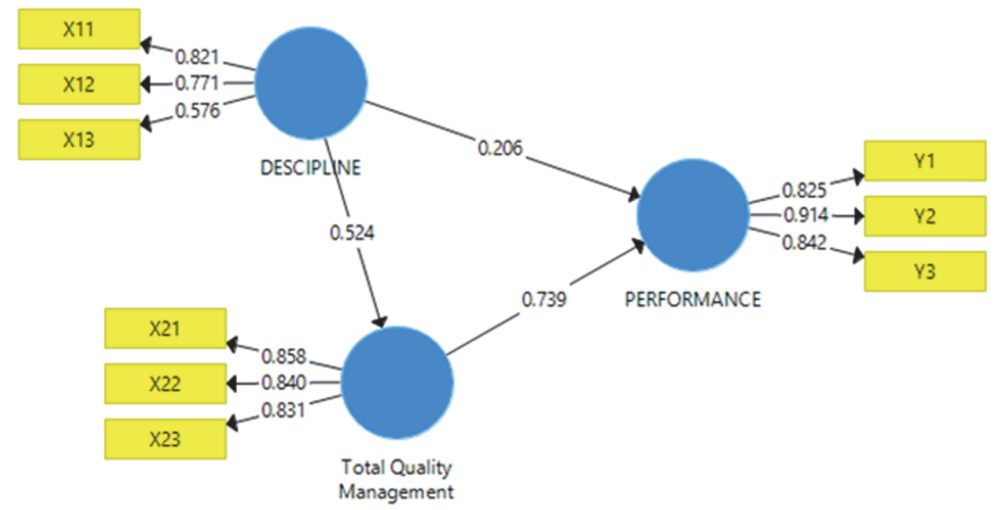

Fig. 2. Initial Partial Least Squares Model

\subsection{Assessing the Outer Model or Measurement Model}

The construct of Discipline, Total Quality Management and performance are analyzed by looking at the convergent validity and reliability of each indicator. The output in Table 1 and Fig. 2 shows the loading factor for the three constructs above the required 0.5 , with a statistical $\mathrm{T}$ value above 1.96 (for a significance level of 0.05 ) which indicates that the construct has a good discriminant validity.

Table 1

\begin{tabular}{|c|c|c|c|c|}
\hline & $\begin{array}{l}\text { Original Sam- } \\
\text { ple }(O)\end{array}$ & $\begin{array}{l}\text { Sample } \\
\text { Mean (M) }\end{array}$ & $\begin{array}{l}\text { Standard } \\
\text { Deviation (STDEV) }\end{array}$ & $\begin{array}{lr}\text { T } & \text { Statistics } \\
(\mid \mathrm{O} / \text { STERR } \mid)\end{array}$ \\
\hline Implementing Rights \& Obligations (X11) & 0.821 & 0.806826 & 0.065698 & 12.503723 \\
\hline Compliance with Regulations (X12) & 0.771 & 0.751905 & 0.086671 & 8.901167 \\
\hline Punctuality (X13) & 0.576 & 0.580383 & 0.121564 & 4.737200 \\
\hline Team work . Scientific Approach. and Unity of Purpose (X21) & 0.858 & 0.855391 & 0.043798 & 19.594001 \\
\hline Continual Improvement (X22) & 0.839 & 0.834157 & 0.053851 & 15.591283 \\
\hline Education and Training. and Engagement and Empowerment (X23) & 0.831 & 0.832843 & 0.028591 & 29.081868 \\
\hline Quantity (Y1) & 0.824 & 0.824099 & 0.032901 & 25.066110 \\
\hline Quality (Y2) & 0.914 & 0.910584 & 0.024942 & 36.663611 \\
\hline Working Accuracy (Y3) & 0.842 & 0.835832 & 0.047139 & 17.853950 \\
\hline
\end{tabular}

Outher Loadings (Mean, STDEV, T-Value)

\subsection{Testing the Structure Model (Inner Model)}

Discriminant reliability (AVE), Cronbach alpha (CA), and composite reliability (CR) were measured. The criteria stated that if discriminant reliability (AVE) is greater than 0.5 , Cronbach alpha is greater than 0.6 and composite reliability is greater 
than 0.7 , the construct is declared reliable. The reliability test shows (Table 2) that all latent constructs have AVE values greater than 0.5 , CA values greater than 0.6 , and $\mathrm{CR}$ values greater than 0.7 . Hence, based on reliability criteria, all items can be declared reliable in measuring latent variables. The measurement model of R-square discipline on total quality management is 0.275 or $27.5 \%$ and discipline on performance through total quality management gives an R-square value of 0.748 which can be interpreted that the discipline variable on performance through total quality management is $74.8 \%$.

Table 2

$\underline{\mathrm{R}-\mathrm{Square} \text { dan Cronbachs Alpha }}$

\begin{tabular}{|c|c|c|c|c|}
\hline & R Square & Average Variance & Cronbach's Alfa & Composite Reliability \\
\hline DESCIPLINE & & 0.534 & 0.644 & 0.771 \\
\hline Total Quality Management & 0.275 & 0.711 & 0.803 & 0.881 \\
\hline PERFORMANCE & 0.748 & 0.742 & 0.827 & 0.896 \\
\hline
\end{tabular}

Table 3

Path Coefficients (Mean, STDEV, T-Values)

\begin{tabular}{|c|c|c|c|c|c|}
\hline & $\begin{array}{l}\text { Original } \\
\text { Sample (O) }\end{array}$ & $\begin{array}{l}\text { Sample Mean } \\
\text { (M) }\end{array}$ & $\begin{array}{l}\text { Standard } \\
\text { Deviation } \\
\text { (STDEV) }\end{array}$ & $\begin{array}{l}\text { T Statistics } \\
(|\mathrm{O} / \mathrm{STERR}|)\end{array}$ & P Values \\
\hline DISCIPLINE $\rightarrow$ PERFORMANCE & 0.206 & 0.202699 & 0.062166 & 3.309323 & 0.002 \\
\hline DISCIPLINE $\rightarrow$ Total Quality Management & 0.524 & 0.536387 & 0.078466 & 6.683717 & 0.000 \\
\hline Total Quality Management $\rightarrow$ PERFORMANCE & 0.739 & 0.740228 & 0.058983 & 12.525655 & 0.000 \\
\hline DISCIPLINE $\rightarrow$ Total Quality Management $\rightarrow$ PERFORMANCE & 0.387 & 0.397 & 0.052 & 7.511 & 0.000 \\
\hline
\end{tabular}

Significant level : T-stats $>1.96$; P-value $>0.05$

Next is the hypothesis test and determines the significance of the influence of exogenous variables on endogenous variables, both directly and indirectly path. Table 3 illustrates that all relationships of the variables are meaningful when the level of significance is five percent, and from the results of data analysis it is found that the magnitude of the parameter coefficient between discipline to performance is 0.206 or $20.6 \%$ and the magnitude of the discipline parameters to performance through Total Quality Management is $(0.524 \times 0.739)=0.387$. Based on the above results, hypotheses 1 and 2 are accepted

\section{Discussion}

\subsection{Effect of work discipline on the performance of the Ambon State Polytechnic educational staff}

The results showed the effect of discipline on the performance of the Ambon State Polytechnic educational staff by $20.6 \%$. This shows that the higher the level of discipline, the better the performance of the educational staff. Work discipline basically has a high role in improving employee performance. High work discipline must always be maintained, even better. Employees who have good work discipline are expected to be able to try as much as possible to complete their work and to produce optimal performance for the organization. Disciplined employees tend to be punctual in carrying out established procedures and have high responsibilities. This relates to the theory of work discipline according to Soejono (1986) which states that good discipline reflects the magnitude of one's sense of responsibility for the tasks assigned to him. This can encourage increased performance and the achievement of objectives, employees, and the community. In other words, work discipline is the main capital that determines the level of employee performance. Indicators of work discipline in this study are carrying out duties and obligations, adherence to regulations and timeliness. Carry out the duties and obligations by looking at the responsibilities on the results of the work, working with established procedures, ready to improve the work if something goes wrong. Obeying the rules that have been established shows that education staff have good work discipline. In this study, measured by not delaying work time, receiving sanctions if violating the rules and obeying the leadership. Furthermore, punctuality includes arriving before working hours, leaving the office with the leader's permission, and using appropriate breaks. Punctuality is a form of employee work discipline by coming on time, and regularly. Carry out the duties and obligations by looking at the responsibilities on the results of the work, working with established procedures, ready to improve the work if something goes wrong. Obeying the rules that have been established shows that education staff have good work discipline. In this study, measured by not delaying work time, receiving sanctions if violating the rules and obeying the leadership. Furthermore, punctuality includes arriving before working hours, leaving the office with the leader's permission, and using appropriate breaks. Punctuality is a form of employee work discipline by coming on time, and regularly. From this explanation it can be concluded that the existence of good work discipline will produce good employee performance, on the contrary if the work discipline is not good it will produce poor employee performance too. This research was also supported by research conducted by Suprayitno and Sukir (2007) which shows that work discipline has a significant positive effect on employee performance. When compared with the value of indirect effects, discipline to performance through Total Quality Management has a smaller value of only $20.6 \%$. The results showed the lowest score of the disciplinary variable on the indicator of timeliness in question is adherence to the use of effective hours of work in accordance with Presidential Decree No. 68 of 1995 which is 37 hours 30 minutes per week or $\geq 7.5$ hours per day. Based on the results of the study we need to 
note the lack of discipline of education personnel, especially adherence to work standards due to the absence of strict sanctions for employees who lack discipline. The use of hours of rest that is less effective, since it is often misused for personal purposes makes the time to re-enter work becomes delayed. It makes their work hours cut off, so that the results of their work are not optimal, work that should be able to be completed in one day, can be completed in 2 or 3 days. When working hours can be optimally implemented it can improve the performance of the Ambon State Polytechnic education staff. Based on research, discipline can improve the performance of Ambon State Polytechnic education staff. This is supported by the results of research by Setiawan et al. (2006) which states that discipline has a positive and significant influence and contributes to improving employee performance, the effect of discipline as measured by indicators compliant with regulations, effective at work (employees finish work quickly), and corrective actions (taking notes on all work).

\subsection{The influence of discipline on performance through total quality management on Ambon State Polytechnic education staff}

Basically Total Quality Management (TQM) is a management science theory that involves everyone in the organization to carry out continuous quality improvement programs for the organization's products, services, processes and environments. Ambon State Polytechnic in an effort to improve employee performance began to implement a Total Quality Management system within the campus environment by involving all existing lines by prioritizing cooperation. The results of the study found that work discipline could improve the performance of the education center through Total Quality Management efforts by $38.7 \%$. The discipline of their work must be directed first in the effort to improve the quality of services, administrative processes and lectures by involving all lines in the Ambon State Polytechnic environment. The relationship between work discipline and Total Quality Management is very close because with the discipline that implements the Total Quality Management system, employee performance will be easy to improve. The results showed that discipline had an important impact on the performance of educational staff through the satisfaction of the practice of Total Quality Management in Ambon State Polytechnic. From this, it can be said that Total Quality Management can bridge the effect of discipline on the performance of the educational staff, however, in the absence of Total Quality Management basically effective work discipline also has a strong influence in improving the performance of the educational staff. In implementing Total Quality Management, teamwork is an aspect that is considered quite important by employees in encouraging the achievement of their performance. here the education staff need to build a good relationship with fellow colleagues. These needs must be able to be grown and developed by education staff, so there is no gap between them and there is a sense of security at work. From the overall research findings, it can be concluded that the effectiveness of teamwork (as an important part in the implementation of Total Quality Management practices) will create a good relationship among the education staff so that it could encourage the feeling of satisfaction of the education staff and ultimately improve the quality of their performance, therefore the education staff needs a tool to build the effectiveness of team work in the implementation of each work. In addition, another aspect that is also considered quite important by education personnel is the culture of the organization. As expressed by Parncharoen et al. (2005) the implementation of organizational quality management is essentially a program of organizational change that requires transformation of organizational culture, processes, and beliefs, So, if the implementation of a quality management system can change the orientation of an organizational culture towards a quality culture, according to the opinion of Hardjosoedarmo (2005) this will improve employee performance and ultimately improve the performance of this organization. In line with the research of Hendricks and Singhal (1999); Ittner and Larcker (1996) that when an organization implements Total Quality Management in an effective way, its performance will be greatly improved from several aspects. In a literature review that discusses the impact of total quality management on organizational performance, Saizarbitoria (2006) shows that there is a positive direct relationship between Total Quality Management and organizational performance.

\section{Conclusion}

Work discipline directly influences the performance of educational staff by $20.6 \%$ and when viewed from the indirect effect of work discipline has a positive effect on performance through total quality management of $38.7 \%$. This means that in improving the performance of educational staff, work discipline should be directed in the total quality management process so that the work process is more focused and focused. But even without a total quality management system, the performance of the teaching staff can still be improved through discipline. So discipline is the main key in improving the performance of education staff, and total quality management is a planned system that is proven to be able to improve performance better. By implementing a total quality management system there will be an increase in the quality of performance and improvement of management in all lines.

\section{References}

Al-Shobaki, S. D., Fouad, R. H., \& Al-Bashir, A. (2010). The implementation of total quality management (TQM) for the banking sector in Jordan. Jordan Journal of Mechanical and Industrial Engineering, 4(2), 304-313.

Bohlander, G., Snell, S., \& Sherman, A. (2001). Managing Human Resource. South Western College Publishing. United State. 
Enny, M. W. (2015). Effect of ISO 900-2008 QMS, Total Quality Management and Work Environment on Job Satisfaction and Employee Performance at Pt Mount Dreams Indonesia in Gresik. The International Journal of Business \& Management, 3(4), 369.

Gharakhani, D., Rahmati, H., Farrokhi, M. R., \& Farahmandian, A. (2013). Total quality management and organizational performance. American Journal of Industrial Engineering, 1(3), 46-50.

Ghozali, I. (2006). Aplikasi analisis multivariate dengan program SPSS.

Handoko, T. H. (2008). Manajemen Personalia dan Sumber Daya. Manusia (edisi 2). Yogyakarta: BPFE.

Hardjosoedarmo, S. (2005). Total Quality Management. Andi. Yogyakarta

Hasibuan, M. S. (2005). Manajemen sumber daya manusia edisi revisi. Bumi Aksara, Jakarta, 288.

Hendricks, K. B., \& Singhal, V. R. (2001). The long-run stock price performance of firms with effective TQM programs. Management Science, 47(3), 359-368.

Ismunawan. (2010). Penerapan Penilaian Kinerja dan Sistem Pengukuran. Jurnal Graduasi, 24, 27 - 29.

Lakhal, L, Pasin, F. and Liman M. (2006). Quality management practices and their impact onperformance. International Journal of Quality \&Reliability Management, 23(6): 625-646

Ittner, C. D., \& Larcker, D. F. (1996). Measuring the impact of quality initiatives on firm financial performance. Advances in the management of organizational quality, 1(1), 1-37.

Mangkunegara, A. P., \& Prabu, A. (2006). Evaluasi Kinerja Sumber Daya Manusia Perusahaan. Bandung: PT. Refika Aditama.

Mangkunegara, A.A., \& Prabu, A. (2013) Manajemen Sumber Daya Manusia Perusahaan, Cetakan Kesebelas, Bandung: PT. Remaja Rosdakarya.

Heriyanto, M., \& Alhudri, S. (2015). Pengaruh Penerapan Total Quality Management (TQM) Terhadap Kinerja Karyawan Pada PT. PLN (Persero) Ranting Bangkinang (Doctoral dissertation, Riau University).

Parncharoen, C., Girardi, A., \& Entrekin, L. (2005). The Impact of Cultural Values on the Succesful Implementation of Total Quality Management: A Comparison between the Australian and Thai Models. Total Quality Management, 5(1), 597-609.

Poernomo, E., \& Timur, A. B. U. P. N. V. J. (2006). Pengaruh kreativitas dan kerjasama tim terhadap kinerja manajer pada PT. Jesslyn K Cakes Indonesia cabang Surabaya. Jurnal Ilmu-Ilmu Ekonomi, 6(2), 102-108.

Suyadi, P. (2004). Filosofi Baru Tentang Manajemen Mutu Terpadu Total Quality Manajemen Abad 21 Studi kasus dan analisis, edisi pertama, PT. Bumi Aksara, Jakarta.

Saizarbitoria, I.H. (2006). How quality management 68. Dooyoung, S., J.G. Kalinowski and G. El-Enein, models influence company results-conclusions of an empirical study based on the Delphi method. Management, Total Quality Management \& Business Excellence, 17(6), 775-794

Setiawan, Budi, \& dan Waridin. (2006). Pengaruh Disiplin Kerja Karyawan dan Budaya Organisasi terhadap Kinerja di Divisi Radiologi RSUP Dokter Kariadi Semarang, 2(2), 181-250.

Siagian, S. (2006). Manajemen Sumber Daya Manusia. Cetakan Ketiga Belas, Jakarta: Bumi Aksara

Sulistyani, A.T., \& Rosidah. (2003).Manajemen Sumber Daya Manusia, Yogyakarta: PT. Graha Ilmu.

Suprayitno, \& Sukir. (2007). Pengaruh Disiplin Kerja Dan Motivasi Kerja Terhadap Kinerja Karyawan. Jurnal Manajemen Sumber Daya Manusia. 2(1), 23-24

Therese, A. J. (2007). Total Quality Management and Performance. JQRM, 24(6), 617-627.

Tjiptono, F., \& Diana, A. (2003). Total Quality Management Edisi Revisi. Yogyakarta: Andi.

Wirawan. (2009). Budaya Dan Iklim Organisasi. Penerbit Kencana. Jakarta.

Yasin, N. A., Ridjal, S., \& Jjufri, M. (2019). Human capital and entrepreneurship and their impact on the productivity of traditional craftsmen. Revista ESPACIOS, 40(04), 8-20.

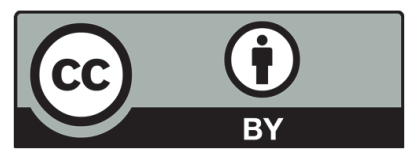

(C) 2020 by the authors; licensee Growing Science, Canada. This is an open access article distributed under the terms and conditions of the Creative Commons Attribution (CC-BY) license (http://creativecommons.org/licenses/by/4.0/). 